\title{
Psikolojik Sözleşme, Örgütsel Adalet, Örgütsel Güven Ve İşyerinde Yalnızlık İlişkisi: Karşılılık Normu Yaklaşımı

\author{
(The Relationship between Psychological Contract, Organizational Justice, Organizational
} Trust and Loneliness at Workplace: The Norm of Reciprocity Perspective)
}

\author{
Ediz GÜRIPEK iD a Berrin GÜZEL iD b \\ a Tokat Gaziosmanpaşa Üniversitesi, Zile Dinçerler Turizm İşletmeciliği ve Otelcilik Yüksekokulu, Tokat, Türkiye. \\ ediz.guripek@yahoo.com \\ b Aydın Adnan Menderes Üniversitesi, Turizm Fakültesi, Aydın, Türkiye. berringuzel@hotmail.com
}

\begin{tabular}{|c|c|}
\hline MAKALE BİLGİSİ & ÖZET \\
\hline $\begin{array}{l}\text { Anahtar Kelimeler: } \\
\text { Karşılılık Normu } \\
\text { Örgütsel Adalet } \\
\text { Psikolojik Sözleşme }\end{array}$ & $\begin{array}{l}\text { Amaç - Yalnızlık sadece sosyal hayat içerisinde değil, aynı zamanda örgüt içerisinde de yaşanan bir } \\
\text { duygudur. Bu duyguyu tetikleyen etkenlerden biri ise güvendir. Adalet algısı ile örgüt ile çalışan } \\
\text { arasındaki ilişkiyi değerlendiren psikolojik sözleşme ise güvenin oluşmasında önemlidir. Bu } \\
\text { kavramlar ise temelde karşılılık normuna dayanmaktadır. Mevcut çalışmanın amacı restoran çalışan } \\
\text { davranışlarının ilgili kavramlar arasındaki ilişkinin karşıllılık normu temelinde açılanmasıdır. }\end{array}$ \\
\hline $\begin{array}{l}\text { Örgütsel Güven } \\
\text { İşyerinde Yalnızlık } \\
\text { Turizm }\end{array}$ & $\begin{array}{l}\text { Yöntem - Araştırmada karşılılık normunu ölçmek amacıyla Wu vd. (2006)'nın geliştirdiği ölçek } \\
\text { kullanılmıştır. Örgütsel adalet ölçeği Niehoff ve Moorman (1993) tarafından geliştirilen üç boyutlu } \\
\text { (dağıtım, işlem ve etkileşim adaleti) ve } 20 \text { ifadeden oluşmaktadır. Psikolojik sözleşmenin çiğnenme } \\
\text { ve ihlali için Robinson ve Morrison (2000)'un geliştirdiği dokuz ifadeli ölçek kullanılmıştır. Örgütsel } \\
\text { güven kavramı } 12 \text { ifadeden oluşan Cook ve Wall (1980) ölçeği ile ölçülmüştür. Ölçek, güvenilir } \\
\text { niyete güven ve yeteneklere güven olmak üzere iki boyut içermektedir. Son olarak işyerinde }\end{array}$ \\
\hline $\begin{array}{l}\text { Gönderilme Tarihi } 20 \text { Ocak } \\
2020\end{array}$ & $\begin{array}{l}\text { yalnızlık ise Wright vd. (2006) tarafından oluşturulan ve Doğan vd. (2009) tarafından da } \\
\text { Türkçeleştirilen ölçek aracılığı ile ölçülmüştür. Araştırma Muğla ilinde faaliyet gösteren restoran }\end{array}$ \\
\hline $\begin{array}{l}\text { Revizyon Tarihi } 1 \text { Haziran } \\
2020\end{array}$ & $\begin{array}{l}\text { işletmeleri çalışanlarını kapsamaktadır. Anket tekniği ile veriler toplanmış, dağıtılan } 500 \text { anketten } \\
391 \text { adet anket veri analizine uygun olarak değerlendirilmiştir ve analizler gerçekleştirilmiştir. }\end{array}$ \\
\hline Kabul Tarihi 18 Haziran 2020 & $\begin{array}{l}\text { Bulgular - Araştırma sonucuna göre karşıllılık normu örgütsel adalet ve psikolojik sözleşme } \\
\text { kavramlarını açılamaktadır. Karşılılık normu örgütsel adaleti arttırırken, psikolojik sözleşme ihlal } \\
\text { ve çiğnenmesini azaltmaktadır. Diğer yandan örgütsel adalet örgütsel güveni arttırırken, psikolojik } \\
\text { sözleşme ihlal ve çiğnenmesi örgütsel adaleti azaltmaktadır. Son olarak örgütsel güven algısı ise } \\
\text { çalışanların işyerinde yalnızlığı azaltmaktadır. }\end{array}$ \\
\hline $\begin{array}{l}\text { Makale Kategorisi: } \\
\text { Araştırma Makalesi }\end{array}$ & $\begin{array}{l}\text { Tartışma - Örgüt içerisinde yükümlülüklerin yerine getirilmemesi, çalışanlarda adalet ve psikolojik } \\
\text { sözleşme ihlal ve çiğnenmesine dair algıları etkilemektedir. Karşılıı̆ı̆̆n olması ile birlikte çalışanlar } \\
\text { örgütü daha adil bir kurum olarak değerlendirirken, çalışanlar örgütlerinin vaatlerini yerine } \\
\text { getirdiklerine de inanmaktadır. Bu da çalışanların güven algılarını arttırırken, işyerindeki yalnızlık } \\
\text { algısını azaltmaktadır. }\end{array}$ \\
\hline ARTICLE INFO & ABSTRACT \\
\hline $\begin{array}{l}\text { Keywords: } \\
\text { Norm of Reciprocity } \\
\text { Organizational Justice } \\
\text { Psychological Contract }\end{array}$ & $\begin{array}{l}\text { Purpose - Loneliness is a feeling not only in social life but also in the organization. One of the factors } \\
\text { that trigger this emotion is trust. The psychological contract that evaluates the perception of justice } \\
\text { and the relationship between the organization and the employee is important in establishing trust. } \\
\text { These concepts are basically based on the reciprocity norm. The aim of the present study is to explain } \\
\text { the relationship between concepts on the basis of the norm of reciprocity. }\end{array}$ \\
\hline $\begin{array}{l}\text { Organizational Trust } \\
\text { Loneliness at Work, Tourism }\end{array}$ & $\begin{array}{l}\text { Design/methodology/approach - In order to measure the norm in the research, Wu et al. (2006) 's } \\
\text { scale was used. The organizational justice scale consists of three dimensions (distribution, } \\
\text { transaction and interaction justice) and } 20 \text { items developed by Niehoff and Moorman (1993). Nine- } \\
\text { item scale developed by Robinson and Morrison (2000) was used for the violation and breach of the } \\
\text { psychological contract. The concept of organizational trust was measured by Cook and Wall (1980) }\end{array}$ \\
\hline $\begin{array}{l}\text { Received } 20 \text { January } 2020 \\
\text { Revised } 1 \text { June } 2020 \\
\text { Accepted } 18 \text { June } 2020\end{array}$ & $\begin{array}{l}\text { scale consisting of } 12 \text { items. The scale includes two dimensions: faith in intentions and confidence in } \\
\text { actions. Finally, loneliness in the workplace is measured by Wright et al. (2006)'s scale which is } \\
\text { translated into Turkish by Doğan et al. (2009). The research includes employees of restaurant in } \\
\text { Muğla. Data were collected with survey technique, } 391 \text { questionnaires of } 500 \text { distributed } \\
\text { questionnaires were evaluated in accordance with data analysis and analyzes were carried out. }\end{array}$ \\
\hline
\end{tabular}


Findings - According to the results of the research, the norm of reciprocity explains the concepts of organizational justice and psychological contract. Reciprocity norm increases organizational justice, while reducing the psychological contract breach and violation. On the other hand, while organizational justice increases organizational trust, breach and violation of the psychological contract decreases organizational justice. Finally, organizational trust perception reduces loneliness at workplace.

Discussion - Failure to fulfill obligations within the organization affects perceptions of employees for violations and breaches of psychological contract and organizational justice. With the provision of reciprocity, employees consider the organization as a fairer organization, while employees believe that their organizations fulfill their promises. This increases the perception of trust of the employees and decreases the perception of loneliness in the workplace.

\section{Gírìş}

Yalnızlık bir insan deneyimidir ve genellikle olumsuzluklar ile kullanılır. Yalnızlık kişinin kendi ile baş başa kalması şeklinde ifade edilmesine rağmen, sadece etrafında kimse olmadığında değil, birçok insan ile birlikte iken de yalnızlık hissedebilir. Birlikte olunan kişilerle anlaşamamak, aynı dili konuşamamak bu yalnızlığı tetikleyebilir (Stobbs, 2004; Rokach, 2014; Zhou, 2018).

Yalnızlığın gerçeğinde diğer insanlar ile iletişimin olmaması (Perlman ve Peplau, 1984) söz konusu iken, işyerinde birbirleri ile etkileşim içindedir. İşyeri ilişkilerini açıklayan sosyal değişim bu ilişkilerin birbirlerine bağımlı olduklarını ve diğer kişinin eylemlerinin belirleyici olduğunu belirtmektedir. Bununla birlikte bu ilişkiler yüksek nitelikli ilişkilere de dönüşme potansiyeline de sahiptir (Cropanzano, 2005). Ancak yine de yalnızlığın bir insan mizacı olarak değil, işyerindeki yalnızlığın nedenlerinin araştırılması önemlidir.

Örgütsel davranış çalışmalarında adalet algısı (Adams, 1965) ve psikolojik sözleşme (Morrison ve Robbinson, 1997) kavramları Homans (1961) ve Blau (1964)'nun sosyal değişim kuramı ile açıklanırken, sosyal değişimin de dayandığı karşılılık normu yaklaşımı daha önce değerlendirilmemiştir. Örneğin Aryee vd. (2002) sosyal değişim yaklaşımı ile özellikle örgütsel adalet ve güven konusundaki ilişkilerin açılanmasının gerekliliğinden bahsetmektedir. Yalnızlığın nedenlerinden güven ilişkisinin nedensel etkilerinin incelenmesini öneren Nyhan ve Marlowe (1997) bu sayede güveni olumlu yönde etkileyen müdahaleler yapılabileceğini de belirtmektedirler. Robinson ve Rousseau (1994) ise psikolojik sözleşme ile güven arasındaki ilişkideki nedenselliğin yönünün bilinmediğini ve her iki yönlü olabileceğini belirtmişlerdir. Mevcut çalışmanın amacı, restoran çalışanlarında psikolojik sözleşme ihlali ve örgütsel adalet algısı ilişkisinin örgütsel güven algısına ve örgütsel güven algısının da işyerinde yalnızlığa etkisinin karşılılık normu ile açıklanması ve modelin test edilmesidir. Bu model aracılı̆̆ı ile örgütsel yalnızlığın kavramlara dair bir karşılılık sonucu yaratıp yaratmadığı belirlenebilecektir.

\section{LİTERATÜR}

\subsection{Karşıllılık Normu}

Değişimin en bilinen kuralı olarak da bilinen (Cropanzano ve Mitchell, 2005) ve işveren ile çalışan davranışları arasındaki karşılıklı etkileşimi açıklayan (Coyle-Shapiro ve Parzefall, 2008) karşıllılık normu, elde edilen yararlar karşılığında yapılan belirli eylemler ve zorunluluklar olarak tanımlanabilir. Bu anlamda geçmiş davranışlara yönelik olarak zorunluluklar ortaya çıkmaktadır. Her ne kadar zaman ve yere göre değişiklik gösterse de kavram evrenselliğini korumaktadır. Karşıllılı normunda birbiri ile ilişkili iki önemli koşul vardır: (1) kişi, kendine yardım edene yardım etmelidir ve (2) kişi, kendine yardım edene zarar vermemelidir (Gouldner, 1960). Karşılılık kavramında sadece uygun karşılığın ne olduğu değil, aynı zamanda karşı tarafın marjinal faydasının da sağlanması gerektiği bilinmelidir (Adams, 1965). Dolayısıyla her iki tarafı da içermesi gerekmektedir (Cole vd., 2002).

Örgüt ilişkilerinde örgüt ile çalışanlar arasında karşılılığın dayalı yükümlülüklerin ne olduğu konusunda Nadin ve Cassell (2007) örgütün çalışana ücret, alınacak kararlarda destek sağlanması, çalışana bağlılık ve sadakat, adil davranma ve esneklik; çalışanların da örgüte esneklik (çalışma saatleri, tatil ve izinler, örgüt içerisinde yaptıkları iş konusunda), örgüte bağlılık ve sadakat ile sorumluluk alma ve girişken olma konularında yükümlü olduğunu belirtir. Hong vd. (2009) ise öz-güvenlik, örgüt-güvenliği, sadakat ve gelişim konularındaki yükümlülükleri çalışanların örgüte; üretim garantisi, gelişme garantisi, örgütsel gelişim ve örgütsel saygınlı konularındaki yükümlülükleri de örgütün çalışana yükümlülükleri olarak 
tanımlamaktadır. Dainty vd. (2004) de örgütün ilişkisel boyutta çalışana adalet ve adil davranma yükümlülüğü taşıdığını belirtmişlerdir.

\section{2. Örgütsel Adalet}

Belirli bir çıktı veya sürecin uygunluğunun değerlendirilmesine dair kişilerin algılarına yönelik, dolayısıyla da öznel olan (Cropanzano ve Greenberg, 1997) adalet kavramı insanın belirsizlik ile baş etmesinde araç olması nedeniyle önemlidir. Örneğin, yöneticiler ile çalışanların arasındaki ilişkinin yararlı olup olmayacağı, çalışma süresi, elde edilecek sonuçlar bu belirsizliklerdendir. Eğer ki adalet, belirsizliğin kaynağına doğrudan yöneltilirse bu belirsizlik ortadan kalkabilir (Colquitt, 2009). Ayrıca örgüt içindeki çelişkilere verilecek tepkileri ve çalışanların beklentilerini etkilemesi yine adaleti önemli hale getirmektedir (Johns ve Saks, 2001).

Adalet kavramının boyutlarının yapısını ve ilişkilerini açıklamaya yönelik çalışmalarda (Gilliland, 2008) (daha detaylı inceleme için bkz. Greenberg, 1990) kavramın kişilerarası ilişkiler ile süreç kontrolüne kadar geniş bir alanı içermesi (Colquitt vd., 2001), diğer bir ifadeyle çok boyutlu yapısı (Robbins ve Judge, 2013), kavramsallaştırmayı farklılaştırmaktadır. Dolayısıyla farklı boyutlarının birbirleri ile ilişkileri, bu boyutların kavramı geliştirip geliştirmediği halen güncelliğini korumaktadır (Colquitt vd., 2001). Nitekim, adaletin çok boyutlu yapısı olsa da kişi, adalet algısını bütüncül bir yargı ile gerçekleştirmekte ve bu bütüncül yargıya dayanarak davranışta bulunmaktadır (detaylı inceleme için bkz. Patel vd., 2012).

Adalet kavramının boyutlarından dă̆ıtım adaleti, ödüllerin miktar ve bölüşümlerinin adil olup olmadığının bilişsel değerlendirilmesidir (Luthans, 2008). Bu anlamda ödüllerin dağıtımı, tarafların statü veya işe katkılarındaki oransal farklılıkları yansıttığı sürece adil olarak algılanmaktadır (Ledford, 1998). Dolayısıla aslında dağıtım adaleti miktar ile ilgili olduğu kadar, kimlerin bu ödülleri aldığı açısından da önemlidir (Robbins ve Judge, 2013). Dağıtımların adaletsiz olarak algılanması, kişilerin duyguları, farkındalıkları ve davranışlarını etkilemektedir (Cohen-Charash ve Spector, 2001). İslem adaleti ise alınan kararların nasıl alındığına (Greenberg ve Baron, 2003) ve çalışanların prosedürleri ne kadar adil algılandığına yöneliktir. Bu anlamda prosedürlerin adil olup olmaması değil, çalışanların onları ne kadar adil algıladığı önemlidir (George ve Jones, 2007). Çıktıların işlem adaletini etkilemesi nedeniyle dağıtım adaletini desteklemekte ve geliştirmektedir (Niehoff ve Moorman, 1993). Leventhal (1980) işlem adaletini; tutarlılık, tarafsızlık, karar kalitesi (doğruluk), düzeltilebilirlik, söz hakkı olması ve etik olması ile açıklamaktadır. Bu altı bileşen ile birlikte, kişiler süreçleri adil olarak algıladıkları ve söz hakları olduğu sürece olumsuz sonuçları kabul etmektedirler (Tyler ve Lind, 1990). Bu anlamda değerlendirme, sistem veya kurumsal özelliklerin değerlendirilmesidir (Folger ve Konovsky, 1989). İşlem adaletinin bir bileşeni olarak da kabul edilen (Tyler ve Blader, 2000) etkileşim adaleti ise kararların uygulanmasında çalışanlara adil davranılıp davranılmadığına dair algıları ifade etmektedir (Kreitner ve Kinicki, 2004). Kişilerarası iletişimin algılanan adaleti olarak da düşünülen (Colquitt, 2009) etkileşim adaleti, örgütün temsilcilerine yönelik tepkilerdir (Bies ve Moag, 1986). Her üç adalet kavramına yönelik tepkiler değerlendirildiğinde, dağıtım adaleti elde edilen çıktılara, işlem adaleti örgütün kendisine ve etkileşim adaleti de örgütün temsilcisi olarak kabul edilen yöneticilere yöneliktir (Cohen-Charash ve Spector, 2001).

\subsection{Psikolojik Sözleşme}

İstihdam ilişkisinde önemli bir bileşen (Shore ve Tetrick, 1994) ve çalışan ile örgüt arasındaki ilişkinin başında oluşan (Robinson ve Morrison, 2000) psikolojik sözleşme 'kişi ve karşı taraf arasında karşıllklı değişim anlaşmasının koşul ve şartlarına yönelik kişinin inançları' olarak tanımlanmaktadır (Rousseau, 1989). Burada temel nokta, karşıllılı temelinde (Robinson ve Rousseau, 1994) yükümlülükler ile tarafları bağlayan bir anlaşma yapıldığına ve bunun karşılığında bir başka yükümlülüğün sunulduğuna dair inançtır (Rousseau, 1989). Sözleşmeyi oluşturan ise verilen sözler değil, bunların karşılıklı olmasıdır (Robinson ve Rousseau, 1994). Dolayısıyla taraflar, karşı taraf da kendi payına düşeni yaptığında yükümlülüklerini yerine getirmektedir. Bu hali ile aslında karşılılık 'yansıtma' niteliğindedir (Robinson ve Morrison, 2000). Geleceğe yönelik sözlerin olmaması/gerçekleşmemesi durumunda taraflar ilişkiye katkı yapmayacak ve ilişki de uzun sürmeyecektir (Robinson ve Rousseau, 1994).

Sözleşme inanç temelli yapısıyla oldukça özneldir ve kişi bu kişisel inancı iyi niyet, adil paylaşım ve güven olarak değerlendirmekte, sözleşmeyi de taraflar arasındaki ilişkinin parçası olarak kabul etmektedir 
(Rousseau, 1989). Ancak bu öznel yapı, aynı sözleşmenin taraflarca aynı şekilde anlaşılmasını engelleyebilir, her iki taraf sözleşmeyi aynı şekilde anladıklarına inanabilirler (Robinson ve Rousseau, 1994).

İlişkide taraflardan birinin kendi yükümlülüklerini yerine getirmemesi durumunda ise ihlal oluşmaktadır (Robinson ve Rousseau, 1994). Ancak Morrison ve Robinson (1997) kavramin ihlal edilmesinin duygusal ve bilişsel değerlendirmeler içermesi nedeniyle ihlal ve çiğneme olarak ikiye ayırmıştır. Buna göre çiğneme (breach), sözleşmenin gereklerinin yapılmamasına yönelik bilişsel değerlendirmeyi; ihlal (violation) ise sözleşmenin yükümlülüklerinin yeterli düzeyde karşılanmaması durumundaki duygusal durumu ifade etmektedir. Ancak yine de öznel yapısı gereği (Rousseau, 1989) gerçekte olmamasına rağmen kişi, sözleşmenin ihlal edildiğini iddia edebilir ki bu da psikolojik sözleşme ihlaline yönelik düşündürücü bir özelliktir (Robinson ve Morrison, 2000).

\section{4. Örgütsel Güven}

Rotter (1967)'in 'bir söz, vaat, sözlü/yazılı ifadeye dair karşı tarafa güvenilebileceğine dair kişinin inanç duyduğu beklenti' olarak tanımladığı güven, sosyal örgütlerde etkililiği arttıran en önemli unsurlardandır. Rempel vd. (1985) güveni, inanç temelinde inanma kavramını gerçeğin daha ötesinde kabul ederek, gelecekteki gelişmelerin kişinin doğru olduğunu ispatlamasına duyulan inanç ile açıklamaktadır. Bu anlamda inancı duygusal bir güvende olmak olarak da görmektedir. Ancak güveni de sadece inanç ile değil, aynı zamanda tahmin edilebilirlik ve bağımlılık ile birlikte açıklamaktadır. Ancak sonrasında Nyhan ve Marlowe (1997) kavramı inanç veya itimat içerir şekilde açıklamıştır.

Güven, karşı tarafın davranışları karşısında incinebilmeye dair kabul olarak değerlendirildiğinde (Mayer vd., 1995; Schoorman vd., 2007), yapabilme becerisini (yeterlilik), yapma isteğini (isteklilik) ve tutarlılı̆̆1 içermektedir (Mayer vd., 1995). Whitener vd. (1998) bu yönlerden ayrı olarak güveni üç özellik ile açıklamaktadır. Bunlardan birincisi karşı tarafın da istekli şekilde davranacağına dair beklenti veya inanç, ikincisi tarafların bu beklenti için karşı tarafı zorlamaması/kontrol edememesi ve üçüncüsü de karşı tarafın eylemlerine dayanması nedeniyle karşı tarafa kısmen bağımlı olmasıdır.

Güven kavramı, güven duyan kişinin güven duyduğu kişiyi gözlemleyerek oluşturduğu algı, inanç ve tutumlarından oluşmktadır (Whitener vd., 1998). Dolayısıyla güvenilir davranıldığında güven duyulması ile kavram karşılılık içerir ki bu karşılılık olumlu ve olumsuz anlamdadır. Deneyim, bir döngü yaratarak güveni arttırabilir veya azaltabilir (Carnevale ve Wechsler, 1992; Mayer vd., 1995; Dirks ve Ferrin, 2002). Ancak daha sonrasındaki çalışmalar, güvenin karşılıklı olması ve bir karşılılık içermek zorunda olmadığını ortaya koymaktadır (Schoorman vd., 2007). Bu anlamda güvenin taraflar arasında bir karşllık içerip içermediği konusu aslında çelişkilidir.

Her ne kadar Levinson (1965) yöneticilerin davranışlarını örgütün davranışları olarak kabul etse de güven konusunda güven boyutları farklı şekilde ele alınır (DeConinck, 2010). Cook ve Wall (1980) işyerinde güveni güvenilir niyete inanç ile yeteneklere güven temelinde olmak üzere iki ve iş arkadaşları ile yönetime olmak üzere de farklı iki boyutta değerlendirmektedir. McKnight vd. (1998) güveni kişilerarası ve sisteme güven olarak ayırmış ve kişilerarası güveni 'bir tarafın diğer bir tarafa olumsuz sonuçlara neden olsa bile göreli güvenlik duygusu ile bağlı olma isteği', sisteme güveni de 'geleceğe yönelik girişim öngörüsünü sağlamak için var olan kişisel olmayan uygun yapıların olması' şeklinde tanımlamıştır. Shockley-Zalabak vd. (2010) ise güvenin sadece örgütsel boyutunu açıklamakta ve bunu 'örgütün iletişim ve davranışlarını hedefler, normlar ve değerler ile birlikte yetkin, açık ve dürüst, ilgili, güvenilir ve tanımlamaya değer olduğuna dair kapsayıcı bir inanç' olarak tanımlamaktadır.

\section{5. İsyerinde Yalnızlık}

Evrensel bir deneyim olarak (Rokach, 2014) insanların sosyal etkileşim ve yakın ilişkilere sahip olma gibi sosyal ihtiyaçları bulunmakta, karşılanmadığında ise kişi yalnızlık hissetmektedir (Weiss, 1973, akt. Chan ve Qiu, 2011). Dolayısıyla yalnızlık bir mizaç değil (Özçelik ve Barsade, 2011), kişinin nitel veya nicel olarak sosyal ilişkilerindeki yetersizlikler sonucunda hissettiği psikolojik bir durumdur (Perlman ve Peplau, 1984). Kişinin kendi algısına dayalı (Wright vd., 2006) olduğu için ortak bir noktada bulunmadığı durumlarda kişi, kalabalıklar içinde de kendini yalnız hissedebilmektedir (Stobbs, 2004). 


\section{E. Güripek - B. Güzel 12/2 (2020) 1915-1932}

Yalnızlık, yaygın şekilde yaşanan olumsuz bir duygu olması nedeniyle (Zhou, 2018) acı doludur ve bu nedenle tolere edilmesi oldukça güçtür (Rokach, 2014). İşyerinde olumsuz sosyal veya duygusal çevre, kötü iş tasarımı ve yetersiz yönetim gibi unsurlar kişinin yalnızlık yaşamasına neden olabilmektedir (Wright, 2005). Dolayısıyla yalnızlık kişiye özel bir duygu olsa da aslında sosyal bir olgudur (Özçelik ve Barsade, 2011). Bir iş ortamında insanlar-arası kaliteli ilişkilerin olmadığını algılandığında oluşan üzüntü ile kendini gösteren (Wright vd., 2006) yalnızlığın olumsuz duyguları göz ardı edilmemelidir (Zhou, 2018).

İşyerinde yalnızlık kavramı çok boyutlu yapısı ile birlikte duygusal yoksunluk ve sosyal arkadaşlık olmak üzere ikiye ayrılmaktadır (Wright vd., 2006). Duygusal yoksunluk, yakın duygusal ilişkilerin olmaması; sosyal arkadaşlık ise sosyal bir ağ ile bütünleşmenin olmamasıdır (Weiss, 1973'ten akt. Chan ve Qui, 2011). Tecrit edilmiş hissetmek veya tecrit edilmek, yabancılaşmak duygusal yalnızlığın içinde yer alırken; paylaşmamak, birlikte zaman geçirmemek ve bir grubun parçası olmamak da sosyal yalnızlığın içinde değerlendirilmektedir (Wright vd., 2006).

Her ne kadar yinelenen örgütsel etkenler çoğunlukla işyeri yalnızlı̆̆ının nedeni olarak görülmese de (Wright, 2005) örgütteki sosyal iklim bu yalnızlığı etkilemektedir (Erdil ve Ertosun, 2011). Kişinin işyerinde kendini yalnız hissettiği durumların değerlendirilmesi, kronik yalnızlı̆̆ın sert sonuçlarını yumuşatmaktadır (Wright vd., 2006) ve örgütün de refahını arttırmaktadır (Özçelik ve Barsade, 2011).

\subsection{Araştırma Hipotezleri}

Adalet kavramının bir karşılılık olup olmadığı yönündeki görüşlerde iki farklı yaklaşım vardır: adaletin sadece karşılıkların tamamlandığında hak olduğuna veya karşlıklar yerine getirilmediğinde bile adaletin sağlanması gerektiği tartışmaları vardır (Buchanan, 1990). Örgütsel bağlamda ise karşılıklı yükümlülükler ile adalet inancı birbiri ile yakın şekilde ve önemli düzeyde ilişkilidir. Kelime olarak 'hak ve hukuka uygunluk; herkese kendine uygun düşeni, kendi hakkı olanı verme, doğruluk' (TDK, 2019) olarak tanımlanan adalete karşın Rousseau (1989) adaletsizlikte sözleşmenin ihlal edilmek zorunluluğu olmadığını, karşılıklı yükümlülüklere dair inanç ile eylemler arasındaki tutarsızlıkların ihlal yarattı̆̆ını belirtimektedir. Dolayısıyla aslında sadece eylemsel olarak değil, karşılıklı yükümlülüklerin yerine getirilmemesi inancı da adaletsizliği oluşturabilmektedir. Bu düşünce ile aşağıdaki hipotez geliştirilmiştir;

H1: Karşıllık normu, çalışanların örgütsel adalet algısını etkilemektedir.

Çalışan ile işveren arasındaki psikolojik sözleşme karşılıklı yükümlülüklere dayanmaktadır (Rousseau, 1989; Robinson ve Rousseau, 1994). Buradan hareketle gelecekte elde edilecek yararlar için yükümlülükler oluşturulur ki bunlar karşılıklı olması gerekmektedir (Robinson ve Rousseau, 1994). Bu anlamda sözleşmedeki karşılılı̆̆ın ilişkinin öncülü niteliğinde olduğunu belirtse de, Rousseau (1989) psikolojik sözleşmeyi karşılllık normundan farklı olduğunu düşünerek, karşılılık normunun evrensel ve değişim temelli olduğunu; psikolojik sözleşmenin de bu karşılılığa verilen değerle oluştuğunu belirtmektedir. Ayrıca, Gouldner (1960)'ın karşlılık normunda sunulan karşılıkların birbirine denk olmasının zorunlu olmadığını ancak psikolojik sözleşmede denk olması gerektiğini belirtmiştir. Blancero ve Ellram (1997) ise psikolojik sözleşmede tek başına karşılılığın önemli bir bileşen olduğunu vurgulamakta ve denklikten bahsetmemektedir.

Psikolojik sözleşmede yükümlülüklerin yerine getirilmemesi Morrison ve Robinson (1997)'un ortaya koyduğu hali ile ihlal ve çiğneme olarak iki farklı boyutta ele alınır. Ancak her iki boyut birbirinden farklı olsa da ihlal konusu bilişsel ve duygusal boyutlar içermesi ile bir arada da ele alınmaktadır. Diğer bir ifadeyle ikisi birbirinden farklı ama ilişkili olsalar da aynı kavramı açıklamaktadır. Psikolojik sözleşmenin temelde bir karşıllılık içermesi, Morrison ve Robinson (1997) yükümlülüklerin yerine getirilmesinde karşllılığın önemli olduğunu ancak araştırılmadığını vurgulaması ve Rousseau (1989)'un belirttiği üzere onun öncülü olduğu düşüncesinden hareketle aşağıdaki hipotez geliştirilmiştir;

H2: Karşlllık normu, psikolojik sözleşme ihlalini etkilemektedir.

Adalet kavramı kendi içerisinde bir sözleşme örneği olarak görülmektedir. Zira sözleşme iyi tanımlanmış bir koşulun, belirli ilkelerinin kabul edileceğini açılamaktadır (Rawls, 1999). Andersson (1996) çalışanın adalet konusunda duyacağı hassasiyetin psikolojik sözleşmesinin ihlal edilmesi durumunda tepki vereceği düşüncesine neden olacağını belirtmiştir. Robinson ve Morrison (2000) psikolojik sözleşmenin ihlali durumunun farklı yapılarda adalet algılarından etkilendiğini belirtirken, Blancero ve Johnson (2001) 


\section{E. Güripek - B. Güzel 12/2 (2020) 1915-1932}

psikolojik sözleşmenin karşılanmasının adalet boyutlarında incelenmesini önermektedir. Ancak Patel vd. (2012)'in adalet algısının bütüncül yargı ile gerçekleştiği ve davranışta bulunulduğu düşüncesinden hareketle aşağıdaki şekilde hipotez geliştirilmiştir:

\section{H3: Restoran çalışanların örgütsel adalet algısı, psikolojik sözleşme ihlalini etkilemektedir.}

Güven kavramı her ne kadar Blau (1964) için örgütsel adalet ile çalışanların tutumları arasındaki ilişkide önemli ve Apaydın (2016) için sosyal değişimin de bir boyutu olsa da, örgütsel güven ile örgütsel adalet ilişkisine yönelik çalışmalar oldukça azdır. Örgütsel güven ile adalet arasındaki güçlü ilişkide (Carnevale ve Wechsler, 1992), güvenin düşük olduğu ortamlarda çalışanlar adalet konusunda daha duyarlıdır. Çalışanlar örgütün kendilerinin gösterdikleri çabaya saygı duymadığını ve değer vermediğini ve adil davranmayacaklarını hissetmektedir (Kickul vd., 2005). Diğer yandan örgütsel adaletin boyutları, örgütsel güvenin boyutlarını farklı şekilde etkilemektedir. Kişilerarasındaki iletişim ile açıklanan (Colquitt, 2009) etkileşim adalet,i yöneticiye (Aryee vd., 2002; DeConinck, 2010) ve onun kararlarına (Bies ve Shapiro, 1987Cohen-Charash ve Spector, 2001) olan güveni belirlemektedir. Bu durum, yöneticiler ile çalışanlar arasındaki değişimle (Aryee vd., 2002) ve lider-üye etkileşimi kalitesi ile (Cohen-Charash ve Spector, 2001) açılanabilir. Diğer yandan Chrobot-Mason (2003) güvenin örgütsel adaleti etkilediğini belirtmektedir. Çalışanın örgüte güveninin yüksek olması ve örgütün adil olduğuna yönelik inanç ile birlikte, örgütün psikolojik sözleşmeyi ihlal etmediğini belirtir.

İşlem adaleti algısı örgüte olan güveni etkilemektedir (DeConinck, 2010). Cohen-Charash ve Spector (2001)'a göre işlem olarak adil algılanan bir örgüt, ilkesel olarak adildir ve bu nedenle güvenilmesi gerekir. Cropanzano vd. (2002) ise işlem adaletinin örgüt ile değil, daha ziyade üst yönetim ile sınırlandırmışlardır. Dağıtım adaleti ise diğerlerinden farklı olarak hem örgüte güven hem de yöneticiye güven ile ilişkilidir. Ancak dağıtım adaleti örgüte güveni doğrudan, yöneticiye güveni dolaylı olarak açılamaktadır (DeConinck, 2010).

Örgütsel güven kavramı, alanyazında her ne kadar örgütsel ve yöneticiye güven (Üstün ve Koca Ballı, 2017; Artar vd., 2019) olarak ayrılmışsa da, Levinson (1965)'a göre çalışanlar örgüt temsilcilerinin davranışlarını örgütün davranışı olarak değerlendirmektedir. Bu anlamda güven kavramı bütün olarak değerlendirilebilir. Bu çalışmada örgütsel adalet algısı da benzer şekildeki bütüncül yapısı ile birlikte (Patel vd., 2012; Ayazlar ve Güzel, 2013) ele alınmış ve aşağıdaki hipotez geliştirilmiştir:

H4: Restoran çalışanların örgütsel adalet algısı, örgütsel güven algısını etkiler.

Değişim temelli iş ilişkilerinde psikolojik sözleşmeler güven içerir (Rousseau, 1989; Atkinson, 2007) ve oldukça önemlidir (Morrison ve Robinson, 1997). Psikolojik sözleşmenin ihlal edilmesi, beklentilerin karşılanmamasından farklıdır. Örgüt ile çalışan arasındaki ilişkiye zarar verildiğini gösterir (Rousseau, 1989). $\mathrm{Bu}$ anlamda iyi niyet ve adil paylaşım gibi konularda psikolojik sözleşmenin ihlal edilmesi, tarafların güvenini azaltmaktadır (Kingshott ve Pecotich, 2007). Özellikle çalışanlar tarafında, işverenin sözleşmeyi ihlal etmesi, karşılıklı yarar sağlayan ilişkiye yönelik temellerin değiştiğini veya ilk baştan yanlış olduğunu göstermektedir (Robinson ve Rousseau, 1994). Bu aynı zamanda işverenin geleceğe yönelik davranışlarına yönelik öngörüleri de olumsuz etkilemektedir (Robinson ve Rousseau, 1994; Morrison ve Robinson, 1997; Whitener vd., 1998). Nitekim tahmin edilebilirlik güven duygusunu arttırmaktadır (Whitener vd., 1998). Robinson ve Rousseau (1994) psikolojik sözleşmenin ihlal edilmesi ve güven arasındaki ilişkide sadece ihlalin güveni değil, güven azalmasının da psikolojik sözleşmenin ihlal edildiği algısına neden olabileceğini belirtmektedir. Her iki koşulda da sonuçta zarar gören bu ilişkinin kurtarılması veya eski haline dönmesi oldukça güçleşmektedir (Rousseau, 1989). Mevcut çalışmada psikolojik sözleşme ihlalinin örgütsel güven algısını azaltacağı düşüncesinden hareketle aşağıdaki hipotez geliştirilmiştir:

H5: Psikolojik sözleşme ihlali, restoran çalı̧̧anlarının örgütsel güven algısını etkilemektedir.

İşyerinde yalnızlık, çalışanlar arasında nitelikli ilişkilerin eksikliği olarak tanımlandığında (Wright, 2005); örgütün ödül/cezalara odaklandığ,ı ancak takım çalışmasının (Zhou, 2018) ve karşılıklı güven duygusunun olmadığı, arkadaşlıkların gelişmediği ve düşük nitelikli ilişkilerin olması işyerinde yalnızlı̆̆a neden olmaktadır (Wright, 2005). Buna göre aşağıdaki hipotez geliştirilmiştir.

H6: Restoran çalışanlarının örgütsel güven algısı, işyerinde yalnızlı̆̆ı etkilemektedir. 
Yukarıda belirtilen hipotezlere göre araştırma modeli oluşturulmuştur. Buna göre karşllılık normu, örgütsel adalet algısını ve psikolojik sözleşme ihlalini; örgütsel adalet alg1sı, psikolojik sözleşme ihlalini; örgütsel adalet algısı ve psikolojik sözleşme ihlali, örgütsel güven algısını; örgütsel güven algısı ise işyerinde yalnızlığı etkilemektedir. Söz konusu hipotezlenen araştırma modeli Şekil 1'de gösterilmektedir.

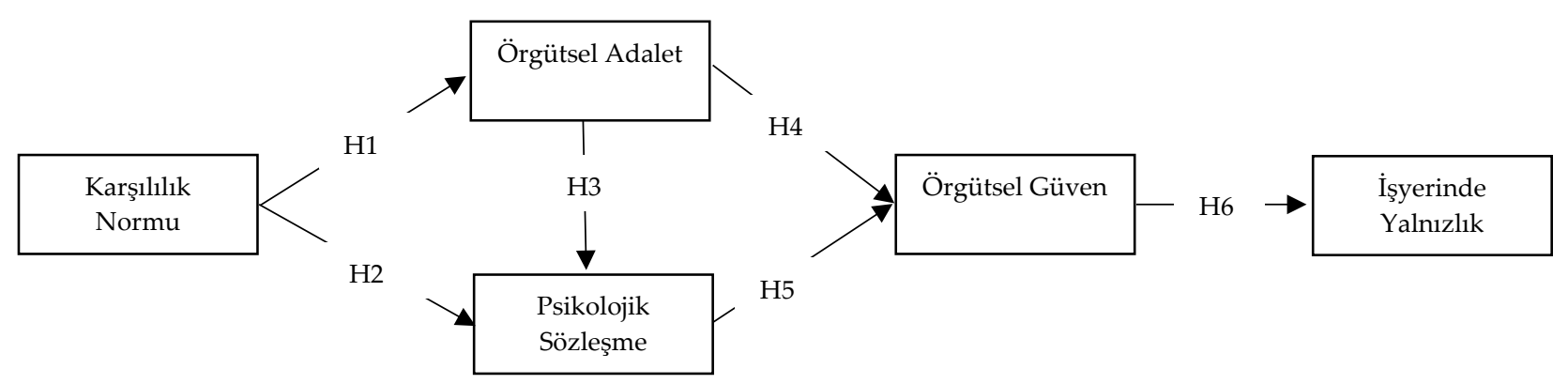

Şekil 1: Hipotezlenen Araştırma Modeli

\section{METODOLOJí}

\section{1. Örneklem ve Veri Toplama}

Araştırmanın evreni Muğla ilinde faaliyette bulunan restoran işletmelerinin çalışanları oluşturmaktadır. Araştırmada kullanılan veriler Mart-Mayıs 2019 tarihleri arasında kolayda örneklem yöntemiyle belirlenen Marmaris, Bodrum, Fethiye, Göcek, Dalaman gibi farklı bölgelerde faaliyet gösteren ve ulaşılabilen, anket yapılmasını kabul eden restoran işletmeleri çalışanlarından elde edilmiştir. Toplamda 500 adet anket formu işletmelere dağıtılmış ve 412 adet anket formu geri dönüşü olmuştur. Bunların 391 tanesi veri analizine uygun olarak değerlendirilmiştir. Araştırmaya katılanlara ait demografik özellikler Tablo 1'de verilmiştir.

Tablo 1. Demografik Özellikler

\begin{tabular}{|c|c|c|c|c|c|c|c|}
\hline & & $\mathbf{N}$ & $\%$ & & & $\mathbf{N}$ & $\%$ \\
\hline \multirow{3}{*}{ Cinsiyet } & Kadin & 138 & 35,3 & \multirow{6}{*}{$\begin{array}{l}\text { İşletme } \\
\text { Çalışma } \\
\text { Süresi }\end{array}$} & 1 Yildan Az & 110 & 28,13 \\
\hline & Erkek & 253 & 64,7 & & $1-5 Y_{11}$ & 223 & 57,03 \\
\hline & Toplam & 391 & 100 & & 6-10 Y 11 & 27 & 6,91 \\
\hline \multirow{5}{*}{ Yaş } & $18-28$ & 185 & 47,31 & & $11-15 Y_{11}$ & 14 & 3,58 \\
\hline & $29-38$ & 142 & 36,32 & & 16 Yll ve Üzeri & 17 & 4,35 \\
\hline & $40-50$ & 54 & 13,81 & & Toplam & 391 & 100 \\
\hline & 51 ve Üzeri & 10 & 2,56 & \multirow{6}{*}{$\begin{array}{l}\text { Sektörde } \\
\text { Çalışma } \\
\text { Süresi }\end{array}$} & 1 Yildan Az & 22 & 5,63 \\
\hline & Toplam & 391 & 100 & & $1-5 Y_{1 l}$ & 200 & 51,15 \\
\hline \multirow{4}{*}{$\begin{array}{l}\text { Kadro } \\
\text { Durumu }\end{array}$} & Kadrolu & 205 & 52,43 & & 6-10 Y 11 & 99 & 25,32 \\
\hline & Sözleşmeli & 109 & 27,88 & & $11-15 Y_{11}$ & 35 & 8,95 \\
\hline & Stajyer & 77 & 19,69 & & $16 Y_{1} 1$ ve Üzeri & 35 & 8,95 \\
\hline & Toplam & 391 & 100 & & Toplam & 391 & 100 \\
\hline
\end{tabular}

Araştırmada demografik veriler değerlendirildiğinde katılımcıların 47,3\%'ü 18-28 yaş aralığında, 64,7\%'si erkek, 52,4\%'ü kadrolu, 57\%'si 1-5 yıldır aynı işletmede çalışmakta olduğu ve 51,2\%'si 1-5 yıldır turizm sektöründe çalışmakta olduğu görülmektedir.

\section{2. Ölçekler}

Çalışmada restoran çalışanlarından karşılılık normu, örgütsel adalet algısı, psikolojik sözleşme, örgütsel güven ve işyerinde yalnızlık ölçeklerini içeren anket formunu doldurmaları istenmiştir. Bunlardan ayrı olarak örneklemin demografik özelliklerini belirlemeye yönelik dört soru sorulmuştur. Bunlar cinsiyet, yaş, sektördeki çalışma süresi ve kadro durumudur. Ankette yer alan ölçekler 5'li Likert tipinde sorulmuş olup, 1Kesinlikle Katılmıyorum ve 5-Kesinlikle Katılıyorum şeklindedir.

Araştırmada kullanılan karşılılık normu ölçeği Wu vd. (2006) tarafından geliştirilmiştir ve orijinal halinde üç boyuttan oluşmaktadır. Ölçeğin orijinalinde genel karşılılık, dengeli karşılılık ve olumsuz karşılılık boyutları yer almaktadır. Ancak, özellikle diğer kavramlar ile ilişkisi olması nedeniyle, sadece genel karşılılık boyutu 
tercih edilmiştir. Genel karşılılık boyutu dört ifade ile ölçülmüştür. Örnek ifadeler “İşletmem kendimi geliştirmeme yardım eder" ve "İşletmem hiçbir karşılık beklemeden benim için bir şeyler yapar" şeklindedir. Örgütsel adalet, Niehoff ve Moorman (1993) tarafından oluşturulan ölçektir. Ölçekte dağıtım, işlem ve etkileşim olmak üzere üç boyut yer almaktadır. Dağıtım adaleti boyutu beş, işlem boyutu adaleti altı ve etkileşim adaleti boyutu ise yedi olmak üzere kavram toplam 20 ifade ile ölçülmüştür. "İş ile ilgili kararlar, tarafsız bir şekilde müdürüm tarafından alınır", "İş yükümün adil olduğuna inanıyorum" ve "İşimle ilgili kararlar aldığında, müdürüm benimle dürüstçe ilgilenir" ifadeleri örnek olarak verilmiştir.

Psikolojik sözleşmenin çiğnenme ve ihlali Robinson ve Morrison (2000) tarafından geliştirilen ve toplamda dokuz ifadeden oluşan ölçek ile ölçülmüştür. Çiğneme boyutu beş, ihlal boyutu ise dört ifade içermektedir. Çiğneme boyutunda 'İşverenimin işe alındığımda bana vermiş olduğu sözleri yerine getirdiğini düşünmekteyim' ve 'İşverenim, işe alım sürecinde verdiği sözlerin hemen hemen hepsini yerine getirdi' ifadeleri; ihlalde ise 'İşyerimin beni aldattığını hissediyorum' ve 'İşyerime karşı oldukça büyük bir öfke hissediyorum' ifadeleri örnektir.

Örgütsel güven, Cook ve Wall (1980) tarafından geliştirilen 12 ifadeli ölçek ile ölçülmüştür. Bu ölçekte inanca güven ve güvenilir niyete inanç olmak üzere iki boyut yer almaktadır. Bu boyutlar da kendi içlerinde yöneticilerine ve iş arkadaşlarına olmak üzere iki alt boyut taşımaktadır. "İşletmem, çalışanlarının beklentilerini karşılamak için gösterdiği çabalarında samimidir", "İş arkadaşlarımın yardıma ihtiyacım olduğunda bana yardım edeceklerine güvenirim", "Yöneticilerim, işlerini etkili şekilde yapıyor gibi görünüyor" örnek ifadeler olarak verilebilir.

İşyerinde yalnızlık ölçeği Wright vd. (2006) tarafından oluşturulan ve Doğan vd. (2009) tarafından Türkçeleştirilen ölçektir. Bu ölçekte duygusal yoksunluk ve sosyal arkadaşlık olmak üzere iki boyut yer almaktadır. "İşyerimdeki ilişkilerimden memnunum" ve "Kendimi iş yerindeki arkadaş grubunun bir parçası olarak hissederim" örnek ifadelerdir.

Veriler yapısal eşitlik modeli aracılı̆̆ı ile AMOS 24 programında analiz edilmiştir. Yapısal eşitlik modeli, değişken seti arasındaki nedensel ilişkileri keşfetmek amacıyla kullanılır. Bu yöntem kovaryans yapı analizi olarak tanımlanır, anlık regresyonların sonuçları korelasyon veya kovaryans düzeyinde değerlendirilir. Mevcut çalışmadaki bağımlı değişken işyeri yalnızlığıdır.

\section{BULGULAR}

Araştırmada kullanılan ölçeklere yönelik olarak öncelikle Doğrulayıcı Faktör Analizi (DFA) yapılmıştır. DFA daha önce saptanan bir modelin ya da hipotezin test edilmesidir. Diğer bir deyişle ölçeklerin, araştırmanın yapıldığı örneklemde de benzer olup olmadığını test etmek üzere yapılmaktadır (Meydan ve Şeşen, 2015). Karşılılık normuna yönelik DFA sonucunda elde edilen bulgular Tablo 1'de gösterilmiştir.

Tablo 1. Karşılılık Normu Doğrulayıcı Faktör Analizi

\begin{tabular}{|c|c|c|c|}
\hline Faktörler ve faktörlere ait ifadeler & $\begin{array}{l}\text { Faktör } \\
\text { Yükleri }\end{array}$ & AVE & $\begin{array}{c}\text { Bileşik } \\
\text { Güvenilirlik } \\
\end{array}$ \\
\hline Faktör 1: Karşılılık Normu & & 0,642 & 0,822 \\
\hline İşletmem, benim onlara kattığımdan daha fazla benimle ilgilenir. & 0,880 & & \\
\hline İşletmem hiçbir karşılık beklemeden benim için bir şeyler yapar. & 0,827 & & \\
\hline $\begin{array}{l}\text { İşletmem, kendilerine yaramayacak olsa bile, kişisel gelişimime yatırım } \\
\text { yapar. }\end{array}$ & 0,756 & & \\
\hline İşletmem kendimi geliştirmeme yardım eder. & 0,734 & & \\
\hline \multirow[t]{2}{*}{ Toplam } & & & 0,822 \\
\hline & $\begin{array}{r}\text { Kaise } \\
B a\end{array}$ & $\begin{array}{l}\text { er Olkin } \\
\text { üreselli }\end{array}$ & $\begin{array}{r}\text { Geçerliliği } 0,789 \\
\text { i Ki Kare 709,422 } \\
\text { Sd } 6 \\
P \text { değeri } 0,000\end{array}$ \\
\hline
\end{tabular}




\section{E. Güripek - B. Güzel 12/2 (2020) 1915-1932}

Karşılılık normu, dört ifadeden oluşmuştur. Bu ifadeler 0,734 ile 0,880 arasında değişen faktör yükleri ile faktöre yüklenmiştir. Güvenilirliği ölçmeye yönelik dört ifadenin bileşik güvenirliliği 0,822 olarak belirlenmiştir.

Tablo 2. Örgütsel Adalet Doğrulayıcı Faktör Analizi

\begin{tabular}{|c|c|c|c|}
\hline Faktörler ve faktörlere ait ifadeler & $\begin{array}{l}\text { Faktör } \\
\text { Yükleri }\end{array}$ & AVE & $\begin{array}{c}\text { Bileşik } \\
\text { Güvenilirlik }\end{array}$ \\
\hline Faktör 1: Dağıttım Adaleti & & 0,672 & 0,873 \\
\hline İş yükümün adil olduğuna inanıyorum. & 0,878 & & \\
\hline Genel olarak aldığım ödül ve terfiler adildir. & 0,851 & & \\
\hline İş sorumluluklarımın adil olduğunu hissediyorum. & 0,840 & & \\
\hline Ücretimin oldukça adil olduğunu düşünüyorum. & 0,807 & & \\
\hline Çalışma saatlerim oldukça adildir. & 0,714 & & \\
\hline Faktör 2: Işslem Adaleti & & 0,585 & 0,805 \\
\hline $\begin{array}{l}\text { Müdürüm, karar almak için topladığı bilgilerin doğru ve eksiksiz olduğundan her } \\
\text { zaman emin olur. }\end{array}$ & 0,848 & & \\
\hline Müdürüm, gerektiğinde çalışanlarına aldığı kararları açıklar ve ek bilgi verir. & 0,819 & & \\
\hline $\begin{array}{l}\text { Kararlar alınmadan önce müdürüm, tüm çalışanlarının konu ile ilgili sıkıntılarını } \\
\text { dinler. }\end{array}$ & 0,804 & & \\
\hline İşle ilgili tüm kararlar, tüm personele aynı ölçüde uygulanır. & 0,711 & & \\
\hline İş ile ilgili kararlar, tarafsız bir şekilde müdürüm tarafından alınır. & 0,618 & & \\
\hline Faktör3: Etkileşim Adaleti & & 0,597 & 0,889 \\
\hline İşimle ilgili kararlar aldığında, müdürüm benimle dürüstçe ilgilenir. & 0,831 & & \\
\hline $\begin{array}{l}\text { İşimle ilgili kararlar aldığında, müdürüm benim haklarımı korumaya özen } \\
\text { gösterir. }\end{array}$ & 0,823 & & \\
\hline İşimle ilgili kararlar aldığında, müdürüm kararların sonuçlarını benimle konuşur. & 0,793 & & \\
\hline İşimle ilgili kararlar aldığında, müdürüm bana saygılı ve gururlu davranır. & 0,789 & & \\
\hline İşimle ilgili kararlar aldığında, müdürüm bana nazik ve ilgili davranır. & 0,757 & & \\
\hline Müdürüm işimle ilgili kararları bana net şekilde açıklar. & 0,754 & & \\
\hline İşimle ilgili kararlarda müdürüm bana haklı gerekçeler sunar. & 0,751 & & \\
\hline İşimle ilgili karar alırken, müdürüm bana da mantıklı gelen açıklamalar yapar. & 0,742 & & \\
\hline $\begin{array}{l}\text { İşimle ilgili kararlar aldığında, müdürüm benim kişisel ihtiyaçlarıma duyarlı } \\
\text { davranır. }\end{array}$ & 0,707 & & \\
\hline \multirow[t]{2}{*}{ Toplam } & & & 0,949 \\
\hline & $\begin{array}{l}\text { Meyer Ol } \\
\text { tt Küresell }\end{array}$ & $\begin{array}{l}n \text { Ölçek } \\
\text { Testi Ki }\end{array}$ & $\begin{array}{r}\text { Jeçerliliği } 0,941 \\
\text { Kare 5902,4932 } \\
\text { Sd } 171 \\
P \text { de ğeri, } 0,000 \\
\end{array}$ \\
\hline
\end{tabular}

Örgütsel adalete dair ilgili DFA sonuçları (Tablo 2) incelendiğinde örgütsel adaletin üç boyuttan oluştuğu görülmektedir. Buna göre boyutlar dağıtım, işlem ve etkileşim adaletidir. Dağıtım adaleti beş ifadeden; işlem adaleti beş ifadeden ve etkileşim adaleti de dokuz ifadeden oluşmaktadır. Dağıtım adaleti ifadeleri 0,714 ile 0,878 arasında faktör yüküne, işlem adaleti ifadeleri 0,618 ile 0,848 arasında faktör yüküne ve etkileşim adaleti ifadeleri 0,707 ile 0,831 arasında faktör yüküne sahiptir. İşlem adaleti boyutunda "Müdürümün aldığı kararlara karşı çıkma hakkımız vardır" ifadesi faktör yük değerinin düşük olması nedeniyle analizlerden çıkarılmıştır (Büyüköztürk, 2002).

Psikolojik sözleşmeye dair ilgili DFA sonuçları (Tablo 3) incelendiğinde psikolojik sözleşmenin iki boyuttan oluştuğu görülmektedir. Buna göre boyutlar psikolojik sözleşmenin çiğnenmesi ve ihlal edilmesidir. Sözleşmenin çiğnenmesi üç ifadeden ve ihlal edilmesi de dört ifadeden oluşmaktadır. Psikolojik sözleşme çiğnenmesine yönelik ifadeler 0,890 ile 0,926 arasında faktör yüküne ve psikolojik sözleşme ihlaline yönelik ifadeler de 0,771 ile 0,951 arasında faktör yüküne sahiptir. Psikolojik sözleşme çiğneme boyutunda "İsyerine katkılarım karşıllğ̆ında bana söz verilen her şeyi almadım" ve "Kendi payıma düşenleri yapmama karşın, işverenim bana verdiği sözlerin çoğunu tutmadı" ifadeleri faktör yük değerlerinin düşük olması nedeniyle analizlerden çıkarılmıştır (Büyüköztürk, 2002). 
E. Güripek - B. Güzel 12/2 (2020) 1915-1932

Tablo 3. Psikolojik Sözleşme Doğrulayıcı Faktör Analizi

\begin{tabular}{|c|c|c|c|}
\hline Faktörler ve faktörlere ait ifadeler & $\begin{array}{l}\text { Faktör } \\
\text { Yükleri }\end{array}$ & AVE & $\begin{array}{c}\text { Bileşik } \\
\text { Güvenilirlik }\end{array}$ \\
\hline Faktör 1: Psikolojik Sözleşmenin İhlali & & 0,702 & 0,869 \\
\hline İşyerimin, aramızdaki anlaşmayı ihlal ettiğini hissediyorum. & 0,951 & & \\
\hline İşyerimin beni aldattığını hissediyorum. & 0,815 & & \\
\hline $\begin{array}{l}\text { İşyerimde bana davranış biçimlerini düşündükçe, fazlasıyla hayal kırıklı̆̆ına } \\
\text { uğradığımı hissediyorum. }\end{array}$ & 0,804 & & \\
\hline İşyerime karşı oldukça büyük bir öfke hissediyorum. & 0,771 & & \\
\hline Faktör 2: Psikolojik Sözleşmenin Çiğnenmesi & & 0,819 & 0,917 \\
\hline $\begin{array}{l}\text { İşverenimin işe alındığımda bana vermiş olduğu sözleri yerine getirdiğini } \\
\text { düşünmekteyim. (R) }\end{array}$ & 0,926 & & \\
\hline Şu ana kadar işverenim bana vermiş olduğu sözleri yerine getirmekte mükemmeldi.(R) & 0,898 & & \\
\hline İşverenim, işe alım sürecinde verdiği sözlerin hemen hemen hepsini yerine getirdi.(R) & 0,890 & & \\
\hline Toplam & & & 0,941 \\
\hline $\begin{array}{r}\text { Kaise } \\
\text { Bar }\end{array}$ & $\begin{array}{l}\text { Meyer Oll } \\
\text { tt Küresel }\end{array}$ & $\begin{array}{l}\text { in Ölçek } \\
\text { ik Testi }\end{array}$ & $\begin{array}{r}\text { Geçerlilĭği } 0,843 \\
\text { Ki Kare } 2219,485 \\
\text { Sd } 21 \\
P \text { değeri } 0,000\end{array}$ \\
\hline
\end{tabular}

(R) ifade ters olarak kodlanmıştır.

Örgütsel güvene dair ilgili DFA sonuçlarında (Tablo 4) örgütsel güvenin iki boyuttan oluştuğu görülmektedir.

Tablo 4. Örgütsel Güven Doğrulayıcı Faktör Analizi

\begin{tabular}{|c|c|c|c|}
\hline Faktörler ve faktörlere ait ifadeler & $\begin{array}{l}\text { Faktör } \\
\text { Yükleri }\end{array}$ & AVE & $\begin{array}{c}\text { Bileşik } \\
\text { Güvenilirlik }\end{array}$ \\
\hline Faktör 1: Güvenilir niyete inanç & & 0,673 & 0,874 \\
\hline $\begin{array}{l}\text { İş arkadaşlarımın yardıma ihtiyacım olduğunda bana yardım edeceklerine } \\
\text { güvenirim. }\end{array}$ & 0,940 & & \\
\hline İş arkadaşlarımın yapacaklarını söyledikleri şeyi yapacaklarına inanırım. & 0,832 & & \\
\hline $\begin{array}{l}\text { İşletmem, çalışanlarının beklentilerini karşılamak için gösterdiği çabalarında } \\
\text { samimidir. }\end{array}$ & 0,820 & & \\
\hline İşimde zorlukla karşılaştığımda iş arkadaşlarımın bana yardım edeceğini biliyorum. & 0,801 & & \\
\hline İşletmemin bana her zaman adil davranacă̆ına güvenirim. & 0,691 & & \\
\hline Faktör 2: Yeteneklere Güven & & 0,549 & 0,801 \\
\hline Birçok iş arkadaşım, birim müdürü yokken bile işlerini yapar. & 0,841 & & \\
\hline İş arkadaşlarımın işle ilgili yeteneklerine güvenirim. & 0,824 & & \\
\hline İşletmenin geleceği için yöneticilerimin duyarlı davranacağına inanabilirim. & 0,769 & & \\
\hline Yöneticilerim, işlerini etkili şekilde yapıyor gibi görünüyor. & 0,733 & & \\
\hline $\begin{array}{l}\text { İşletmemdeki diğer çalışanların, dikkatsiz davranarak benim işimi } \\
\text { zorlaştırmayacağına inanırım. }\end{array}$ & 0,651 & & \\
\hline Ĕ̆er daha iyi bir yönetici bulamazsa, işletmemin geleceği çok parlak olmayacak. & 0,598 & & \\
\hline Toplam & & & 0,911 \\
\hline \multicolumn{4}{|c|}{$\begin{array}{r}\text { Kaiser Meyer Olkin Ölçek Geçerliliği 0,870 } \\
\text { Barlett Küresellik Testi Ki Kare 2725,1035 } \\
\text { Sd } 55 \\
P \text { değeri } 0,000\end{array}$} \\
\hline
\end{tabular}

(R) ifade ters olarak kodlanmıştır.

Tablo 4'e göre örgütsel güven boyutları, güvenilir niyete inanç ve yeteneklere güvendir. Güvenilir niyete inanç boyutu beş ifadeden ve yeteneklere güven boyutu da altı ifadeden oluşmaktadır. Güvenilir niyete inanca yönelik ifadeler 0,691 ile 0,940 arasında faktör yüküne ve yeteneklere güvene yönelik ifadeler de 0,598 ile 0,841 arasında faktör yüküne sahiptir. Güvenilir niyete inanç boyutunda "İşletmem, çalışanlarını kandırarak iş yaptırmaya hazırdır" ifadesi faktör yük değeri düşük olması nedeniyle analizlerden çıkarılmıştır (Büyüköztürk, 2002). 


\section{E. Güripek - B. Güzel 12/2 (2020) 1915-1932}

Son olarak örgütsel yalnızlığa dair ilgili DFA sonuçları (Tablo 5) örgütsel yalnızlığın iki boyuttan oluştuğunu göstermektedir. Buna göre boyutlar duygusal ve sosyal yalnızlıktır. Örgütsel yalnızlığın sosyal boyutu altı ifadeden ve duygusal boyutu da sekiz ifadeden oluşmaktadır. Sosyal yalnızlığa dair ifadeler 0,647 ile 0,804 arasında faktör yüküne ve duygusal yalnızlığa dair ifadeler de 0,594 ile 0,703 arasında faktör yüküne sahiptir. Sosyal yalnızlık boyutunda "İ̧ yerinde istediğimde kişisel düşüncelerimi paylaşabileceğgim kimse yoktur" ve "İ̧̧ ortamında baskı altındayken iş arkadaşlarım tarafından yalnız bırakıldığımı hissederim" ifadeleri faktör yük değerleri düşük olması nedeniyle analizlerden çıkarılmıştır (Büyüköztürk, 2002).

Tablo 5. İşyerinde Yalnızlık Doğrulayıcı Faktör Analizi

\begin{tabular}{|c|c|c|c|}
\hline Faktörler ve faktörlere ait ifadeler & $\begin{array}{l}\text { Faktör } \\
\text { Yükleri }\end{array}$ & AVE & $\begin{array}{c}\text { Bileşik } \\
\text { Güvenilirlik }\end{array}$ \\
\hline Faktör 1: Sosyal Yalnızlık & & 0,530 & 0,782 \\
\hline Kendimi iş yerindeki arkadaş grubunun bir parçası olarak hissederim. & 0,804 & & \\
\hline İş yerinde beni dinleme zahmetinde bulunan insanlar vardır. & 0,754 & & \\
\hline İş yerinde sosyal ilişkilerim vardır. & 0,746 & & \\
\hline İş yerinde gerektiğinde işle ilgili günlük sorunlarımı konuşabileceğim biri var. & 0,741 & & \\
\hline İş yerimdeki sosyal etkinliklere (piknik, parti, yemek vs.) katılırım. & 0,666 & & \\
\hline İş yerinde mola zamanlarında beraber vakit geçirebileceğim biri vardır. & 0,647 & & \\
\hline Faktör 2: Duygusal Yalnızlik & & 0,437 & 0,731 \\
\hline Çalıştığım iş yerinde dostluk anlayışı hakimdir. & 0,703 & & \\
\hline İş yerimdeki ilişkilerimden memnunum. & 0,702 & & \\
\hline İş yerindeyken kendimi genel bir boşluk duygusu içinde hissederim. & 0,695 & & \\
\hline Çoğunlukla iş arkadaşlarımın bana mesafeli durduklarını hissediyorum. & 0,671 & & \\
\hline Kendimi iş arkadaşlarımdan duygusal olarak uzak hissediyorum. & 0,665 & & \\
\hline İş arkadaşlarımla birlikteyken çoğu zaman kendimi dışlanmış hissediyorum. & 0,626 & & \\
\hline $\begin{array}{l}\text { İş yerinde çoğu zaman diğer çalışanlarla birlikte aramda bir kopukluk } \\
\text { hissederim. }\end{array}$ & 0,623 & & \\
\hline Birlikte çalıştığım insanlarla arama mesafe koyduğumu hissediyorum. & 0,594 & & \\
\hline Toplam & & & 0,859 \\
\hline \multicolumn{4}{|c|}{$\begin{array}{r}\text { Kaiser Meyer Olkin Ölçek Geçerliliği 0,915 } \\
\text { Barlett Küresellik Testi Ki Kare 3463,513 } \\
\text { Sd } 91 \\
P \text { değeri 0,000 }\end{array}$} \\
\hline
\end{tabular}

Bileşik güvenilirlik (C.R.) katsayısının 0,7'nin üstünde olması güvenilir olarak değerlendirilmektedir (Yaşlığlu, 2017). Tüm bileşik güvenilirlikler incelendiğinde en düşük değer yalnızlığın alt boyutu olan duygusal yalnızlıkta 0,731 olarak tespit edilmiş ve güvenilir olduğu belirlenmiştir.

Çalışmada önerilen model analiz edilmiş ve faktör yükü düşük olan $(<0,60)$ örgütsel adalet ölçeğinin işlem adaleti6 kodlu ifade, psikolojik sözleşme ölçeğinin sözleşme çiğneme4 ve sözleşme çiğneme5 kodlu ifadeleri, örgütsel güven ölçeğinin güvenilir niyete güven3 kodlu ifade, işyerinde yalnızlık ölçeğinin duygusal yalnızlk1 ve sosyal yalnızlık4 kodlu ifadeleri analizden çıkarılmıştır (Büyüköztürk, 2002). Yapılan doğrulayıcı faktör analizine ait model uyum indeksi değerleri Tablo 6' da gösterilmiştir.

Tablo 6. Doğrulayıcı Faktör Analizi Uyum Endeksi Değerleri

\begin{tabular}{cccc}
\hline & $\begin{array}{c}\text { MODİFIKASYON } \\
\text { ÖNCESI }\end{array}$ & $\begin{array}{c}\text { MODİFIKASON } \\
\text { SONRASI }\end{array}$ & SONUÇ \\
\hline X $^{2}$ & 5879,246 & 3036,812 & İyi Uyum \\
X $^{2}$ S.D. & $5879,246 / 1750=3,360$ & $3036,812 / 1356=2,240$ & Kabul Edilebilir Uyum \\
NFI &, 713 & $\mathbf{0 , 8 3 9}$ & Kabul Edilebilir Uyum \\
TLI (NNFI) &, 769 & $\mathbf{0 , 8 9 4}$ & Kabul Edilebilir Uyum \\
IFI &, 780 & $\mathbf{0 , 9 0 4}$ & Kabul Edilebilir Uyum \\
CFI &, 779 & $\mathbf{0 , 9 0 3}$ & İyi Uyum \\
RMSEA & 0,78 & $\mathbf{0 , 0 5 6}$ & İyi Uyum \\
RMR & 0,123 & $\mathbf{0 , 0 7 5}$ & Kabul Edilebilir Uyum \\
PGFI &, 582 & $\mathbf{0 , 6 8 4}$ &
\end{tabular}




\section{E. Güripek - B. Güzel 12/2 (2020) 1915-1932}

Geriye kalan 55 ifadeye ait uyuym indeksi değerlerine göre modelde gerekli modifikasyonlar yapıldıktan sonra tekrar analiz edilmiştir. Doğrulayıcı faktör analizi sonuçlarına göre genel modelin $X^{2}$ uyum testine göre iyi uyum gösterdiği, karşılaştırmalı uyum indekslerinin kabul edilebilir düzeyde ya da yakın oldukları (NFI, NNFI, IFI, CFI, RMSEA), artık temelli uyum indeksine göre ise (RMR) iyi uyum sağladığı Tablo 6'da görülmektedir (bkz. Meydan ve Şeşen, 2015, Yaşlığlu, 2017).

Tablo 7. Ortalamalar ve Standart Sapmalar

\begin{tabular}{lcc}
\hline & Ortalama & Standart Sapma \\
\hline Etkileşim Adaleti & 3,72 & 0,845 \\
Güvenilir Niyete İnanç & 3,67 & 0,881 \\
İşlem Adaleti & 3,63 & 0,908 \\
Yeteneklere Güven & 3,58 & 0,840 \\
Karşlılık Normu & 3,44 & 0,937 \\
Dağıtım Adaleti & 3,38 & 1,020 \\
Psikolojik Sözleşme-Çiğneme & 2,47 & 1,095 \\
Duygusal Yalnızlık & 2,27 & 0,909 \\
Sosyal Yalnıllık & 2,22 & 0,905 \\
Psikolojik Sözleşme- İhlal & 2,19 & 1,060 \\
\hline
\end{tabular}

Ölçeklerin ve faktör analizleri sonucunda elde edilen boyutların aritmetik ortalamaları ve standart sapmaları belirlenmiştir. Elde edilen bulgular Tablo 7'de verilmiştir. Buna göre psikolojik sözleşme ihlali ölçeğinin 2,19 ile en düşük ve örgütsel adalet ölçeğinin etkileşim adaletinin 3,72 ile en yüksek ortalamaya sahip olduğu görülmektedir. Diğer bir ifadeyle katılımcılar, psikolojik sözleşmenin ihlal edilmediğini düşünmektedirler. Katılımcıların yöneticileri ile etkileşimlerinin ise yüksek düzeyde olduğu görülmektedir.

Değişkenler arasındaki ilişkileri belirlemek için yol analizi yapılmıştır. Yol analizi, diğer analizlere göre (çoklu regresyon vb.) bir değişkenin analizde aynı anda bağımlı ve bağımsız değişken olarak kullanılmasına ve birden fazla bağımlı değişken tanımlanmasına olanak vermektedir (Meydan ve Şeşen, 2015: 27-28).

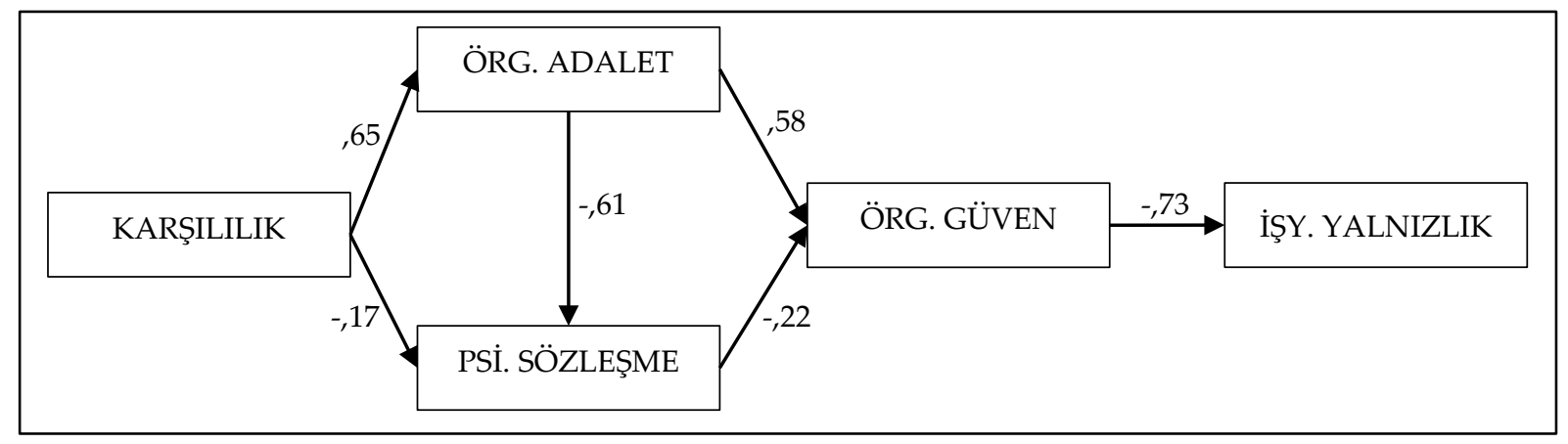

Şekil 2. Yapısal Modelin Yol Analizi Etki Değerleri

Şekil 2'de ve Tablo 8'de görüldüğü üzere karşılllık normunun örgütsel adaletin \%65'ini, psikolojik sözleşmenin \%17'sini açıklamaktadır. Örgütsel adalet psikolojik sözleşmenin \%61'ini açıklamaktadır. Örgütsel adalet örgütsel güvenin \%58'ini açıklamakta, psikolojik sözleşme ise örgütsel güvenin \%22'sini açıklamaktadır. Örgütsel güven ise işyerinde yalnızlığın \%73'ünü açıklamaktadır. 
Tablo 8. Regresyon Analizleri

\begin{tabular}{|c|c|c|c|c|c|c|}
\hline 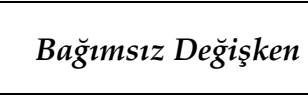 & Bağımlı Değişken & $\begin{array}{c}\text { Tahmini } \\
\text { Regresyon }\end{array}$ & $\begin{array}{c}\text { Standardize } \\
\text { Regresyon }\end{array}$ & S.E. & C.R. & $P$ \\
\hline Karşılılık Normu & Örgütsel Adalet &, 563 & 648 & ,034 & 16,790 & * \\
\hline Karşılılık Normu & Psikolojik Sözleşme &,- 167 &,- 167 & ,046 & $-3,651$ & * \\
\hline Örgütsel Adalet & Psikolojik Sözleşme &,- 701 &,- 607 & 053 & $-13,279$ & * \\
\hline Örgütsel Adalet & Örgütsel Güven & ,555 & ,581 & ,045 & 12,264 & * \\
\hline Psikolojik Sözleşme & Örgütsel Güven &,- 183 &,- 222 & ,039 & $-4,680$ & * \\
\hline Örgütsel Güven & İşyerinde Yalnızlık &,- 736 &,- 731 & ,035 & $-21,148$ & * \\
\hline
\end{tabular}

${ }^{*} \mathrm{p} \leq 0,001$

Sonuç olarak karşılılık normu örgütsel adalet algısını olumlu yönde etkilemektedir. Karşılılık normu psikolojik sözleşme ihlalini ise negatif yönlü etkilemekte, diğer bir ifadeyle çalışanlar yöneticilerin ve örgütün karşılılık normuna uyduklarında psikolojik sözleşme kurallarına uyulduğunu düşünmektedir. Benzer sonuç örgütsel adalet algısı ile psikolojik sözleşme arasında da vardır. Örgütsel adalet algısı arttı̆̆ında, psikolojik sözleşme ihlali azalmakta ancak örgütsel güven artmaktadır. Psikolojik sözleşme ihlali arttığında ise, örgütsel güven azalmaktadır. Son olarak örgütsel güven arttı̆̆ında çalışanların kendilerini yalnız hissetmedikleri görülmektedir.

\section{TARTIŞMA VE SONUÇ}

Mevcut çalışmanın amacı restoran çalışanlarında örgütsel adalet algısı ve psikolojik sözleşme ihlalinin birbiri ile ilişkisinin, örgütsel güvene ve örgütsel güvenin de işyerindeki yalnızlığa etkilerinin karşılılık normu yaklaşımı ile açıklanmasıdır. Araştırmada karşılılık normu, örgütsel adalet algısı ve psikolojik sözleşmeyi; örgütsel adalet algısı psikolojik sözleşme ve örgütsel güveni; psikolojik sözleşme örgütsel güveni ve örgütsel güven de örgütsel yalnızlığı etkilemektedir. Ayrıca elde edilen modelin iyi uyum endeksleri içermesi ile söz konusu modelin desteklendiği görülmektedir.

Araştırmaya göre restoran çalışanlarının etkileşim adaleti algıları, güvenilir niyete inanç, işlem adaleti algısıve yeteneklere güven algıları diğerlerinden daha yüksektir. Adalet ve güven kavramı çalışanların diğerlerinden daha yüksek hissettiği kavramlardır. Örgütsel adalet kavramı içerisinde çalışanlar yüksek düzeyde etkileşim adaletini yaşadıklarını belirtmiştir. Bu anlamda çalışanlar, yöneticilerinin kendilerinin haklarını koruduklarını ve kendileri ile dürüst şekilde ilgilendiklerini, alınan kararların sonuçlarını paylaştıklarını belirtmektedir. Bunu sırasıyla işlem ve dağıtım adaleti algısı izlemektedir. Çalışanlar alınan kararlarda elde edinilen bilgilerin doğru olduğunu ve alınan kararların gerekçelerinin açıklandığını belirtmektedir. Bu iki boyutuna kıyasla çalışanlar örgüt içerisinde gerek iş yükünün gerekse ödül, terfi ve ücret gibi kaynakların adaleti konusuna inanmakla birlikte kaynak dağıtımına dair algılar daha düşük düzeydedir. Dolayısıyla kaynaklar, dağıtım adaletinin temelinde olan eşitlik ilkesinde (Adams, 1965) dağıtılmasa da yöneticilerin çalışanlar ile ilişkilerinde ve alınan kararların açıklanmasında temel olan saygı ve nezaket gibi konulara (Colquitt vd., 2001) önem verdiği söylenebilir.

Adalet kavramını güven kavramı izlemektedir. Güven kavramı içerisinde de güvenilir niyete inanç kavramı önceliklidir. Çalışanlar iş arkadaşlarının kendilerine yardımcı olacağına ve söylediklerini yapacaklarına ve işletmenin de bunun karşılığında çalışanlarının beklentilerini karşılaması konusunda samimi olduğuna dair bir güven duygusunu taşımaktadır. Diğer yandan yüksek olmakla birlikte, güvenilir niyete inanca göre yeteneklere güven kavramı daha düşük düzeydedir. Bu anlamda çalışanlar iş arkadaşlarının yönetici olmadığı durumlarda bile iş arkadaşlarının işlerini yapacaklarını, yöneticilerinin işletmenin çıkarlarının korunması konusunda duyarlı olacağını düşünmektedir. Dolayısıyla çalışanlar, sadece kendilerinin ve yöneticilerin kendilerinin değil, aynı zamanda işletmenin de çıkarlarının korunduğuna dair bir algı içerisinde yöneticilerine güven duymaktadır.

Mevcut çalışmanın temel amacı oluşturulan araştırma modelinin test edilmesidir. Araştırmaya göre karşılılık normu örgütsel adalet algısını etkilemektedir. Bu bulgu Rousseau (1989)'nun düşüncesini desteklemektedir. Örgüt içerisinde yükümlülüklerin yerine getirilmemesi çalışanlarda adalet algısını etkilemektedir. Adalet algısının geçmişten bu yana, Platon tarafından karşı çıkılması ve bu yöndeki görüşlerin günümüzde de devam ediyor ve karşıt olacak şekilde teleolojik anlayışlarla da açıklanıyor olmasına rağmen, karşılılık ile açıklandığı 
(Johnston, 2011) göz önüne alındığında elde edilen bulgu temelde adalet kavramının karşıllılı ile açıklanabilirliğini destekleyen bir bulgudur ve bu yönüyle oldukça önemlidir.

Diğer yandan karşılılık normu, psikolojik sözleşmenin ihlal edildiğine ve çiğnendiğine dair algıyı olumsuz etkilemektedir. İşletmenin çalışanlarına yatırım yapması ve çalışanlarının kişisel gelişimlerine katkıda bulunması, çalışanların işletmenin onlara verdiği sözleri yerine getirdiği düşüncesini oluşturmaktadır (Rousseau, 1989; Robinson ve Rousseau, 1994). Ayrıca çalışanların, işletmenin verdiği sözleri yerine getirdiğine dair bilişsel bir değerlendirme yapmalarını sağlamaktadır. Bunula birlikte çalışanların işletme ile yaptıkları anlaşmayı ihlal etmediği algısı da yaratmakta, çalışanlar da kendilerini aldatılmamış hissetmektedir. Psikolojik sözleşmenin temelde yükümlülükler ve değişim içermesi göz önüne alındığında kavram sosyal değişime dayansa da (Morrison ve Robinson, 1997; Robinson ve Rousseau, 1994), sosyal değişimin de karşılılık normunu temel aldığı (Wikhamn ve Hall, 2012) düşünüldüğünde mevcut çalışma karşılılık normunun psikolojik sözleşmenin dolaylı olarak değil, doğrudan da belirleyicisi olduğunu göstermesi yönüyle önemlidir. Aynı zamanda mevcut bulgu Robinson ve Rousseau (1994)'ün de belirttiği üzere sözleşmenin karşılıklı olması halinde oluştuğu düşüncesini de desteklemektedir.

Alanyazın (Andersson, 1996; Robinson ve Morrison, 2000) ile benzer olarak araştırmada elde edilen diğer bir sonuç ise adalet algısının psikolojik sözleşme ihlalini azaltmasıdır. Çalışmada çalışanların etkileşim adaleti algısı, işlem ve dağıtım adaleti algısına kıyasla daha yüksektir. Bu anlamda yöneticilerin çalışanları ile ilgilenmesi, çalışanların haklarını korumaya yönelik çabalarda bulunması çalışanlar için kararların ne şekilde alındığı ve süreçler ile birlikte örgüt içindeki iş yükü ve kaynakların dağıtımından daha önemli olarak değerlendirilmektedir. Diğer yandan çalışanlar psikolojik anlaşmaların duygusal yönüyle daha az yaşandığını, bilişsel olarak daha yüksek düzeyde yaşandığını belirtmiştir. Bu anlamda çalışanlar işletmelerinin kendilerini aldatmadığını düşünmekte ve işletmeye karşı daha az öfke duyarken, verdiği sözlerin tamamen yerine getirilmediğini de belirtmiştir. Elde edilen sonuca göre çalışanların örgüt içindeki adalet algısı ile birlikte çalışanlar kendilerini daha az aldatıldıklarını, kararların kendilerine açıklanması ve yöneticilerin çalışanların çıkarlarını korumasının çalışanların duygusal ve bilişsel yönüyle örgüt tarafından verilen vaatlerin çoğunluğunun karşılandığını düşünmelerini sağlamaktadır.

İşletmede çalışanların örgütsel adalet algıları, örgüte olan güvenlerini arttırmaktadır. Patel vd. (2012) ve Ayazlar ve Güzel (2013) çalışmalarına benzer şekilde değerlendirilen güven ile yine Patel vd. (2012)'in açıklaması doğrultusunda bütüncül şekilde ele alınan örgütsel adalet ilişkisine yönelik olarak mevcut çalışmada elde edilen bulgu Carnevale ve Wechsler (1992) bulgusu ile benzerdir. Çalışanların iş arkadaşlarının yardıma ihtiyacı olan çalışanlara yardım edeceğine duyulan güven, yapacaklarını söyledikleri şeyi yapmalarına duyulan inanç ve yöneticinin işyerinde olmaması halinde bile işlerini yapması, çalışanların iş arkadaşlarına duyduğu güveni göstermektedir. Örgütün çalışanlarına aldığı kararları açıklaması ve onlarla etkileşim içerisinde olması, bir şeffaflık olarak düşünüldüğünde, çalışanlar lider-üye etkileşimi (CohenCharash ve Spector, 2001) temelinde örgüte ve iş arkadaşlarına karşı güven duymaktadır. Diğer yandan yapılan işlerin çalışanlara açık şekilde açıklanması ve çalışanların bilgilendirilmesi örgütsel güveni arttırmaktadir.

Araştırmada elde edilen diğer bir sonuca göre psikolojik sözleşmeye uyulması ve taraflarca bunların yükümlülüklerinin yerine getirilmesi örgütsel güveni arttırmaktadır. Kingshott ve Pecotich (2007) ile benzer olan bu bulguda çalışanların duygusal olarak örgütün kendisini aldatmadığı düşüncesi ile birlikte, çalışanlar örgüte güven beslemektedir. Psikolojik sözleşme sosyal değişime (Morrison ve Robinson, 1997; Robinson ve Rousseau, 1994) dayanırken, aynı zamanda sosyal değişim kavramı kendi içerisinde güven kavramını barındırmaktadır (Blau, 1964; Apaydın, 2016). Dolayısıyla aslında psikolojik sözleşmenin güveni etkilediği bir ilişkide, kavramın içinde bulunan farklı bir kavramı etkilediği de düşünülmelidir. Yine de güven kavramının tahmin edilebilirlikten etkilendiği (Whitener vd., 1998) düşünüldüğünde, güvenin farklı bir noktada psikolojik sözleşmeden etkilenmesi ile açıklanabilir.

Araştırmada elde edilen son sonuç ise örgütsel güvenin örgütsel yalnızlığı etkilemesidir ki bu Wright (2005) ile benzer bir sonuçtur. İşletmede çalışanların ağırlıklı olarak duygusal yalnızlığı, sosyal yalnızlığa kıyasla daha yoğun şekilde yaşamaktadır. Bu anlamda çalışanlar sosyal ilişkilerinin olduğunu ve kendini bir arkadaş grubunun parçası olarak hissetmesine rağmen işyerinde dostluk anlayışının olmadığını ve kendini boşluk duygusu içinde hissettiklerini belirtmektedir. 
Elde edilen bulgular sektörel açıdan değerlendirildiğinde ise, çalışanlar örgüt içerisinde adalet ve güven kavramlarına ağırlıklı hissetmekte ve bunları diğer kavramlara göre daha yoğun değerlendirmektedir. Her ne kadar özellikle iş ilişkilerinin karşılılık temeline dayandığı düşünülse de yöneticilerin adalet ve güven kavramlarının çalışanlar tarafından daha yoğun şekilde değerlendirildiği ve algılandığına dair farkındalığının olması gerekmektedir. Bu durumda, yöneticilerin özellikle adalet konusunda dağıtım adaletine önem vermesi gerekmektedir. Zira çalışanlar bu boyutu daha düşük olarak değerlendirmektedir. Yöneticilerin işletmenin ücret ve terfi-ödül gibi kıt kaynaklarının dağıtımında daha adil olmaya önem vermesi gerekmektedir. Diğer yandan çalışanların örgüt içerisinde duygusal bir yalnızlık yaşadığı görülmektedir. Bu anlamda örgüt içerisindeki ilişkilerin kişinin kendini yalnız hissetmesinin önüne geçer şekilde değerlendirilmesi ve bu ilişkilerin de yönetilmesi gerektiği düşünülebilir.

Mevcut çalışmanın birtakım sınırlılıkları bulunmaktadır. Bu sınırlılıklardan biri karşılılık normunun sadece bir boyutu ile ilgili modelin açıklanmasıdır. Her ne kadar Sahlins (1972) tipolojisine uygun şekilde ölçek tasarlanmış olsa da Wu vd. (2006) tarafından geliştirilen ölçek üç boyutlu yapısında mevcut araştırmada genel boyutu değerlendirilmiştir. Bu anlamda dengeli ve olumsuz karşılılık boyutlarının yaratacağı sonuçlar bilinmemektedir. Diğer yandan çalışmada kavramların boyutlarının değerlendirilmemesidir. Gelecekteki çalışmalara yönelik olarak örgütsel adalet kavramı Greenberg (1990), psikolojik sözleşme Morrison ve Robinson (1997), örgütsel güvenin Cook ve Wall (1980) çalışmasında oluşan boyutlar veya McKnight vd. (1998)'in belirttiği ve örgütsel yalnızlığın da Wright vd. (2006)'in saptadığı şekilde boyutlandırılması önerilmektedir. Ayrıca çalışmada karşılılık normunun doğrudan etkisi incelenmiş olmakla birlikte, sosyal değişim aracıllğı ile değerlendirilmesinin hem karşılılık normunun sosyal değişimi hem de dolaylı etkisini açıklayabilir.

\section{KAYNAKLAR}

Adams, J. S. (1965). Inequity in Social Exchange, Advances in Experimental Social Psychology, 2, 267-299. Academic Press.

Apaydın, M. (2016). Sosyal Değişim, Psikolojik Sözleşme İhlali, Örgütsel Sinizm ve İşten Ayrılma Niyeti: Bodrum Örneği. Adnan Menderes Üniversitesi Sosyal Bilimler Enstitüsü Yayınlanmamış Yükseklisans Tezi, Aydın.

Artar, M., Adıgüzel, Z. ve Erdil, O. (2019). Örgütlerde yöneticiye duyulan güvenin, psikolojik sözleşme ihlali, örgütsel dışlanma ve iş tatmini arasındaki ilişkilerin incelenmesi, İşletme Araştırmalar Dergisi (ISARDER), 11 (3), 1417-1432.

Aryee, S., Budhwar, P. S. ve Chen, Z. X. (2002). Trust as a mediator of the relationship between organizational justice and work outcomes: test of a social exchange model, Journal of Organizational Behavior: The International Journal of Industrial, Occupational and Organizational Psychology and Behavior, 23 (3), 267285.

Atkinson, C. (2007). Trust and the psychological contract, Employee Relations, 29 (3), 227-246.

Ayazlar, G. ve Güzel, B. (2013). Örgütsel Adaletin otel çalışanlarının işten ayrılma niyeti ve işyerinde sapma davranışına etkisi, Seyahat ve Otel İşletmeciliği Dergisi, 10 (3), 6-23.

Bies, R. J., ve Moag, J. F. (1986). Interactional Justice: Communication Criteria of Fairness, Lewicki, R. J., Sheppard, B. H. ve Bazerman, M. H. (Eds.), Research on Negotiations in Organizations, CT, JAI Press, 4355.

Blancero, D. ve Ellram, L. (1997). Strategic supplier partnering: a psychological contract perspective, International Journal of Physical Distribution \& Logistics Management, 27 (9/10), 616-629.

Blau, P. M. (1964). Exchange and Power in Social Life, New York, John Wiley.

Buchanan, A. (1990). Justice as reciprocity versus subject-centered justice, Philosophy \& Public Affairs, 19 (3), 227-252.

Büyüköztürk, Ş. (2002). Faktör analizi: temel kavramlar ve ölçek geliştirmede kullanımı, Kuram ve Uygulamada Eğitim Yönetimi Dergisi, 32 (Güz), 470-483. 


\section{E. Güripek - B. Güzel 12/2 (2020) 1915-1932}

Carnevale, D. G. ve Wechsler, B. (1992). Trust in the public sector: individual and organizational determinants, Administration \& Society, 23 (4), 471-494.

Chan, S. H. ve Qiu, H. H. (2011). Loneliness, job satisfaction, and organizational commitment of migrant workers: empirical evidence from China, The International Journal of Human Resource Management, 22 (5), 1109-1127.

Cohen-Charash, Y. ve Spector, P. E. (2001). The role of justice in organizations: a meta-analysis, Organizational Behavior and Human Decision Processes, 86 (2), 278-321.

Cole, M. S., Schaninger Jr, W. S., ve Harris, S. G. (2002). The workplace social exchange network: a multilevel, conceptual examination, Group \& Organization Management, 27 (1), 142-167.

Colquitt, J. A. (2009), Two decades of organizational justice: findings, controversies, and future directions, Barling, J. and Cooper, C. L. (Eds.), The SAGE Handbook of Organizational Behavior, Sage Publications, USA. 73-88.

Colquitt, J. A., Conlon, D. E., Wesson, M. J., Porter, C. O. ve Ng, K. Y. (2001). Justice at the millennium: a metaanalytic review of 25 years of organizational justice research, Journal of Applied Psychology, 86 (3), 425445.

Cook, J. ve Wall, T. (1980). New work attitude measures of trust, organizational commitment and personal need non-fulfilment, Journal of Occupational Psychology, 53 (1), 39-52.

Coyle-Shapiro, J. A.M, ve Parzefall, M. (2008). Psychological contracts, Cooper, C. L. ve Barling, J. (Eds.), The SAGE Handbook of Organizational Behavior, London, Sage Publications, 17-34.

Cropanzano, R. ve Greenberg, J. (1997). Progress in organizational justice: tunneling through the maze, International Review of Industrial and Organizational Psychology, 12, 317-372.

Cropanzano, R. ve Mitchell, M. S. (2005). Social exchange theory: an interdisciplinary review, Journal of Management, 31 (6), 874-900.

Cropanzano, R., Prehar, C. A. ve Chen, P. Y. (2002). Using Social exchange theory to distinguish procedural from interactional justice, Group \& Organization Management, 27 (3), 324-351.

Dainty, A. R., Raiden, A. B., ve Neale, R. H. (2004). Psychological contract expectations of construction project managers, Engineering, Construction and Architectural Management, 11 (1), 33-44.

DeConinck, J. B. (2010). The effect of organizational justice, perceived organizational support, and perceived supervisor support on marketing employees' level of trust, Journal of Business Research, 63 (12), 13491355.

Dirks, K. T. ve Ferrin, D. L. (2002). Trust in leadership: meta-analytic findings and implications for research and practice, Journal of Applied Psychology, 87 (4), 611-628.

Doğan, T., Çetin, B. ve Sungur, M. Z. (2009). İş yaşamında yalnızlık ölçeği Türkçe formunun geçerlilik ve güvenilirlik çalışması, Anadolu Psikiyatri Dergisi, 10 (6), 271-277.

Erdil, O. ve Ertosun, Ö. G. (2011). The relationship between social climate and loneliness in the workplace and effects on employee well-being, Procedia-Social and Behavioral Sciences, 24, 505-525.

Folger, R. ve Konovsky, M. A. (1989). Effects of procedural and distributive justice on reactions to pay raise decisions, Academy of Management Journal, 32 (1), 115-130.

George, J. M. ve Jones, G. R. (2007). Understanding and Managing Organizational Behavior, 5th Edition. USA, Prentice Hall.

Gilliland, S. (2008). The tails of justice: a critical examination of the dimensionality of organizational justice constructs, Human Resource Management Review, 18 (4), 271-281.

Gouldner, A. W. (1960). The norm of reciprocity: a preliminary statement, American Sociological Review, 25, 161178.

Greenberg, J. (1990). Organizational justice: yesterday, today, and tomorrow, Journal of Management, 16 (2), 399-432.

Greenberg, J. ve Baron, R. A. (2003). Behavior in Organizations: Understanding and Managing the Human Side of Work. Eighth Edition. USA, Prentice Hall.

Homans, G. C. (1961). Social Behavior: Its elementary forms, NewYork: Harcourt, Brace and World. 


\section{E. Güripek - B. Güzel 12/2 (2020) 1915-1932}

Hong, C., Hui, Q., ve Ru-yin, L. (2009). Content and structure of China coal mine operators' psychological contract, Procedia Earth and Planetary Science, 1 (1), 1617-1626.

Johns, G. ve Saks, A. M. (2001). Understanding and Managing Life at Work, Organizational Behavior, Fifth Edition, Toronto, Addison Wesley Longman.

Kickul, J., Gundry, L. K. ve Posig, M. (2005). Does trust matter? the relationship between equity sensitivity and perceived organizational justice, Journal of Business Ethics, 56 (3), 205-218.

Kingshott, R. P. J. ve Pecotich, A. (2007). The impact of psychological contracts on trust and commitment in supplier-distributor relationships, European Journal of Marketing, 41 (9/10), 1053-1072.

Kreitner, R. ve Kinicki, A. (2004). Organizational Behaviour, 6th Edition, USA, McGraw Hill.

Ledford, G. E. (1998). Justice, Nicholson, N. (ed.), The Blackwell Encyclopedic Dictionary of Organizational Behavior, UK, Blackwell Business, 278-280.

Leventhal, G. S. (1980). What Should Be Done with Equity Theory? New Approaches to the Study of Fairness in Social Relationships, Gergen, K. J., Greenberg M. S. ve Willis, R. H. (Eds.), Social Exchange: Advances in Theory and Research, NY, Plenum Press, 27-55.

Levinson, H. (1965). Reciprocation: The relationship between man and organization, Administrative Science Quarterly, 9 (4), 370-390.

Luthans, F. (2008). Organizational Behavior. Eleventh Edition. New York, McGraw-Hill.

Mayer, R. C., Davis, J. H. ve Schoorman, F. D. (1995). An integrative model of organizational trust, Academy of Management Review, 20 (3), 709-734.

McKnight, D. H., Cummings, L. L. ve Chervany, N. L. (1998). Initial trust formation in new organizational relationships, Academy of Management Review, 23 (3), 473-490.

Meydan, C. H. ve Şeşen, H. (2015). Yapısal Eşitlik Modellemesi, AMOS Uygulamaları (2.Baskı). Detay Yayıncılık, Ankara.

Morrison, E. W. ve Robinson, S. L. (1997). When employees feel betrayed: a model of how psychological contract violation develops, Academy of Management Review, 22 (1), 226-256.

Nadin, S., ve Cassell, C. (2007). New deal for old? exploring the psychological contract in a small firm environment, International Small Business Journal, 25 (4), 417-443.

Niehoff, B. P. ve Moorman, R. H. (1993). Justice as a mediator of the relationship between methods of monitoring and organizational citizenship behavior, Academy of Management Journal, 36 (3), 527-556.

Nyhan, R. C. ve Marlowe Jr, H. A. (1997). Development and psychometric properties of the organizational trust inventory, Evaluation Review, 21 (5), 614-635.

Özçelik, H., ve Barsade, S. (2011). Work loneliness and employee performance, Academy of Management Proceedings, 2011(1), 1-6.

Patel, C., Budhwar, P. ve Varma, A. (2012). Overall justice, work group identification and work outcomes: test of moderated mediation process, Journal of World Business, 47 (2), 213-222.

Perlman, D. ve Peplau, L. A. (1984). Loneliness Research: A Survey of Empirical Findings, L. A. Peplau ve S. Goldston (Eds.), Preventing the Harmful Consequences of Severe and Persistent Loneliness, U.S. Government Printing Office, DDH Publication No. ADM 84-1312, 13-46.

Rawls, J. (1999). A Theory of Justice, Revised Edition, USA, Harvard University Press.

Rempel, J. K., Holmes, J. G. ve Zanna, M. P. (1985). Trust in close relationships, Journal of Personality and Social Psychology, 49 (1), 95-112.

Robbins, S. P. ve Judge, T. A. (2013). Organizational Behavior, USA, Pearson.

Robinson, S. L. ve Rousseau, D. M. (1994). Violating the psychological contract: not the exception but the norm, Journal of Organizational Behavior, 15 (3), 245-259.

Robinson, S. L. ve Wolfe Morrison, E. (2000). The development of psychological contract breach and violation: a longitudinal study, Journal of Organizational Behavior, 21 (5), 525-546.

Rokach, A. (2014). Leadership and loneliness, International Journal of Leadership and Change, 2 (1), 48-58. 


\section{E. Güripek - B. Güzel 12/2 (2020) 1915-1932}

Rotter, J. B. (1967). A new scale for the measurement of interpersonal trust, Journal of Personality, 35 (4), 651665.

Rousseau, D. M. (1989). Psychological and implied contracts in organizations, Employee Responsibilities and Rights Journal, 2 (2), 121-139.

Sahlins, M. (1972). Stone Age Economics, New York: Aldine de Gruyter.

Schoorman, F. D., Mayer, R. C. ve Davis, J. H. (2007). An integrative model of organizational trust: past, present, and future, Academy of Management Review, 32 (2), 344-354.

Shockley-Zalabak, P. S., Morreale S. ve Hackman, M. (2010). Building the High Trust Organization. Strategies for Supporting Five Key Dimensions of Trust, USA, John Wiley \& Sons.

Shore, L. M. ve Tetrick, L. E. (1994). The psychological contract as an explanatory framework, Trends in Organizational Behavior, 1, 91-109.

Stobbs, C. (2004). Isolation in the workplace: taking control, finding a way forward, In Practice, 26 (6), 336-338.

Türk Dil Kurumu Genel Sözlük (2019). Adalet, https://sozluk.gov.tr/

Tyler, T. T., ve Lind, E. A. (1990). Intrinsic versus community-based justice models: when does group membership matter?, Journal of Social Issues, 46 (1), 83-94.

Tyler, T. R., \& Blader, S. L. (2000). Essays in Social Psychology. Cooperation in Groups: Procedural Justice, Social Identity, and Behavioral Engagement, USA, Psychology Press.

Üstün, F. ve Koca Ballı, A. İ. (2017). Çalışanların örgütsel güven düzeyleri ile demografik özellikleri arasındaki ilişki: bir örnek olay çalışması, International Journal of Social And Humanities Sciences (IJSHS), 1 (2), 2038.

Weiss, R. S. 1973. Loneliness: The Experience of Emotional and Social Isolation, Cambridge, MA: MIT Press.

Whitener, E. M., Brodt, S. E., Korsgaard, M. A. ve Werner, J. M. (1998). Managers as initiators of trust: an exchange relationship framework for understanding managerial trustworthy behavior, Academy of Management Review, 23 (3), 513-530.

Wikhamn, W. ve Hall, A. T. (2012). Social exchange in a Swedish work environment, International Journal of Business and Social Science, 3 (23), 56-64.

Wright, S. L. (2005). Loneliness in the Workplace, University of Canterbury PhD Thesis in Psychology.

Wright, S. L., Burt, C. D. ve Strongman, K. T. (2006). Loneliness in the workplace: construct definition and scale development, New Zealand Journal of Psychology, 35 (2), 59-68.

Wu, J. B., Hom, P. W., Tetrick, L. E., Shore, L. M., Jia, L., Li, C. ve Song, L. J. (2006). The norm of reciprocity: scale development and validation in the Chinese context, Management and Organization Review, 2 (3), 377-402.

Yaşlığlu, M.M. (2017). Sosyal bilimlerde faktör analizi ve geçerlilik: keşfedici ve doğrulayıcı faktör analizlerinin kullanılması, İstanbul Üniversitesi İşletme Fakültesi Dergisi, 46, 74-85.

Zhou, X. (2018). A review of researches workplace loneliness, Psychology, 9 (5), 1005-1022. 